\title{
Metazoan endoparasites of Serrasalmus marginatus (Characiformes: Serrasalminae) in the Negro River, Pantanal, Brazil
}

\author{
Metazoários endoparasitos de Serrasalmus marginatus (Characiformes: Serrasalminae) \\ no Rio Negro, Pantanal, Brasil
}

Wagner Vicentin ${ }^{1 *}$; Kelly Regina Ibarrola Vieira ${ }^{1}$; Fábio Edir dos Santos Costa ${ }^{2}$; Ricardo Massato Takemoto ${ }^{3}$; Luiz Eduardo Roland Tavares ${ }^{4}$; Fernando Paiva ${ }^{4}$

\begin{abstract}
${ }^{1}$ Universidade Federal de Mato Grosso do Sul - UFMS
${ }^{2}$ Laboratório de Ictiologia, Centro de Pesquisas em Biodiversidade, Universidade Estadual de Mato Grosso do Sul - UEMS

${ }^{3}$ Laboratório de Ictioparasitologia, Núcleo de Pesquisas em Limnologia, Ictiologia e Aquicultura (Nupélia), Universidade Estadual de Maringá - UEM

${ }^{4}$ Departamento de Parasitologia Veterinária, Universidade Federal de Mato Grosso do Sul - UFMS
\end{abstract}

Received March 15, 2010

Accepted April 19, 2010

\begin{abstract}
In order to inventory the metazoan endoparasites of Serrasalmus marginatus, 91 specimens were examined. They were captured in the Negro River in Pantanal wetland, State of Mato Grosso do Sul, Central-Western Brazil, from October 2007 to August 2008. Parasites of six taxa were recovered: Procamallanus (Spirocamallanus) inopinatus, Contracaecum sp. (Nematoda), metacercarial type Diplostomulum (Digenea), Brevimulticaecum sp. (Nematoda) and Sebekia oxycephala, Subtriquetra sp. 1 and Subtriquetra sp. 2 (Pentastomida). The latter five species are reported for the first time in S. marginatus.
\end{abstract}

Keywords: Parasites, prevalence, intensity of infection, freshwater fish, piranha.

\section{Resumo}

Com o objetivo de inventariar os metazoários endoparasitos em Serrasalmus marginatus, no Rio Negro, Pantanal, Mato Grosso do Sul, Brasil, foram examinados 91 espécimes capturados no período de outubro de 2007 a agosto de 2008. Foram registrados seis táxons parasitos: Procamallanus (Spirocamallanus) inopinatus, Contracaecum sp. (Nematoda), metacercária do tipo Diplostomulum (Digenea); Brevimulticaecum sp. (Nematoda); e Sebekia oxycephala, Subtriquetra sp. 1 e Subtriquetra sp. 2 (Pentastomida). As últimas cinco espécies citadas são registradas pela primeira vez em $S$. marginatus.

Palavras-chave: Parasitos, prevalência, intensidade de infecção, peixe de água doce, piranha.

Studies on the parasitofauna of piranha Serrasalmus marginatus (Valenciennes, 1837) are scarce and mostly have focused on the taxonomy of some groups. The most remarkable reports on endoparasites in S. marginatus include that of Tanaka (2000) who reported Procamallanus (Spirocamallanus) inopinatus, specimens of Capilariidae, Railliet, 1915, and Kritskyia sp. and that of Böeger et al. (2001) who described Kritskyia annakohnae in ureters and urinary bladder, both studies in the Paraná River basin. The

\footnotetext{
*Corresponding author: Wagner Vicentin

Programa de Pós-Graduação em Ecologia e Conservação,

Universidade Federal de Mato Grosso do Sul - UFMS,

CEP 79070-900, Campo Grande - MS, Brazil;

e-mail: wagnervicentin.bio@gmail.com
}

hydrographic network of the Pantanal, with a variety of species of teleost fishes, has few records on parasite faunas, including piranha ( $S$. marginatus) that is widely distributed in the Paraguay River basin.

Thus, with the aim of registering species composition of metazoan endoparasites in $S$. marginatus, there were necropsied 91 specimens caught with hooks and cast nets from October 2007 to August 2008. Six collections were performed in the middle of the main channel of Negro River (19 $9^{\circ} 35^{\prime} 20.04$ " S and $56^{\circ} 11^{\prime} 4.19^{\prime}$ W), a tributary of Paraguay River, Pantanal, State of Mato Grosso do Sul, Central-Western Brazil.

The procedures of necropsy, specimen collection, preparation and conservation of endoparasites were performed according to 
Eiras et al. (2006). The recovered parasites were compared with deposited specimens from the Helminthological Collection of Oswaldo Cruz Institute (CHIOC). Representative specimens of parasites were deposited in the Zoological Collection of Reference at Universidade Federal do Mato Grosso do Sul, such as the host (ZUFMS-PIS No. 3086). Parasitological descriptors were calculated according to Bush et al. (1997).

We found six endoparasite species (Table 1). The metacercarial type Diplostomulum, comprising the genera Diplostomum Nordmann, 1832, Neodiplostomum Railliet, 1919 and Alaria Schrank, 1788 (NIEWIADOMSKA, 2002), was determined by morphology of the reserve bladder with three longitudinal canals (one median and two lateral with ramifications directed posteriorly) connected anteriorly, posterior to the pharynx, and posteriorly, anterior to the ventral sucker.

The observed morphological characteristics in $P$. (S.) inopinatus are consistent with Moravec descriptions (MORAVEC et al., 1997), except for eight cephalic papillae arranged in two circles around the oral opening as the recovered specimens had only four cephalic papillae. Some individuals of $P$. $(S$.) inopinatus were compared with the voucher specimen CHIOC 31.324, host: Leporinus sp., Machado River, State of Rondônia, Brazil (GIESE et al., 2009). The specimen was visibly smaller, but with the same morphological structures of the one collected in the present study. This parasite is well documented in the literature and has been described in different fish species (PAVANELLI et al., 2004), including $S$. marginatus (TANAKA, 2000).

The first report of Brevimulticaecum sp. was of adult specimens in freshwater stingrays Potamotrygon motoro (Müller \& Henle, 1841) by Rego (1979) in the Salobra River, State of Mato Grosso do Sul, and later Sprent (1990) described this species and named it Brevimulticaecum regoi. With respect to teleost fishes, in the neotropical region, there are reports on parasitic larvae of the Brevimulticaecum in the following fishes: Gymnotus carapo Linnaeus, 1758 and Loricariichthys brunneus (Hancock, 1828) in Venezuela (MORAVEC et al., 1997) and Leporinus friderici (Bloch, 1794),
L. lacustris Amaral Campos, 1945, L. obtusidens (Valenciennes, 1837) and L. elongatus Valenciennes, 1850, in Brazil (GUIDELLI, 2006). Some specimens were compared to voucher specimens CHIOC 36.977, host Potamotrygon falkneri Castex \& Maciel, 1963, Paraná River, State of Paraná, Brazil (LACERDA, 2007). It was not possible to compare the ventriculus in the specimen because of overlapping body parts of the voucher specimen in permanent mounting.

Some larvae of Contracaecum sp. were compared with voucher specimen CHIOC 35.521, host: Geophagus brasiliensis, Guandu River, State of Rio de Janeiro, Brazil (AZEVEDO et al., 2006). It was not found any morphological difference among them. Larvae of Contracaecum sp. have been reported in different fish species including S. marginatus (PAVANELLI et al., 2004).

Larvae of Sebekia oxycephala were compared with voucher specimens CHIOC 32.445, host: Pygocentrus nattereri (Kner, 1958) and CHIOC 32.447, host: Pseudoplatystoma corruscans Spix \& Agassiz, 1829, both in the Cuiabá River, State of Mato Grosso, Brazil (REGO; EIRAS, 1989). It was not found any morphological difference between voucher and collected specimens.

Pentastomids of genus Subtriquetra were divided into two morphospecies due to differences in body size, mouth, hooks and spines that are larger in Subtriquetra sp. 2. It was not possible to identify the species due to missing larvae descriptions of these pentastomids. Some individuals of both morphospecies were compared with larvae of S. subtriquetra (Diesing, 1836) CHIOC 17.697, reported in Hoplias malabaricus (Bloch, 1794) in the Salobra River, State of Mato Grosso do Sul, Brazil (TRAVASSOS; FREITAS, 1940), and with some larvae of Subtriquetra CHIOC 11.424, hots: P. nattereri, Salobra River, State of Mato Grosso do Sul (unpublished information). The specimens collected showed morphological similarities with both voucher specimens.

It is the first report of metacercarial type Diplostomulum and larvae of Brevimulticaecum sp., Sebekia oxycephala and Subtriquetra spp. parasitizing S. marginatus.

Table 1. Metazoan endoparasites reported in Serrasalmus marginatus caught in the Negro River (19³5'20.04” S and 56 $11^{\prime} 4.19^{\prime \prime}$ W), Pantanal, State of Mato Grosso do Sul, Brazil, from October 2007 to August 2008.

\begin{tabular}{|c|c|c|c|c|c|}
\hline Parasites & SI & $\mathbf{P}(\%)$ & $\mathrm{MA} \pm \mathrm{SD}$ & $\mathrm{MI} \pm \mathrm{SD}$ & RV \\
\hline \multicolumn{6}{|l|}{ Digenea } \\
\hline Metacercarial type Diplostomulum Poirier, 1886 & inside swimming bladder & 1.10 & $0.10 \pm 0.10$ & 1 & -- \\
\hline \multicolumn{6}{|l|}{ Nematoda } \\
\hline $\begin{array}{l}\text { Procamallanus (S.) inopinatus } \\
\text { (ZUFMS-INV No. 002) }\end{array}$ & cecum and intestine & 5.49 & $0.05 \pm 0.22$ & 1 & --- \\
\hline Brevimulticaecum sp. (ZUFMS-INV No. 003) & stomach tissue and mesentery & 16.48 & $10.46 \pm 41.47$ & $63.46 \pm 86.33$ & $3-324$ \\
\hline Contracaecum sp. (ZUFMS-INV No. 004) & $\begin{array}{l}\text { stomach tissue, cecum and } \\
\text { mesentery }\end{array}$ & 51.65 & $1.63 \pm 3.09$ & $3.17 \pm 3.7$ & $1-15$ \\
\hline \multicolumn{6}{|l|}{ Pentastomida } \\
\hline $\begin{array}{l}\text { Sebekia oxycephala (Diesing, 1835) } \\
\text { (ZUFMS-INV No. 001) }\end{array}$ & body cavity & 7.69 & $0.10 \pm 0.40$ & $1.42 \pm 0.53$ & $1-2$ \\
\hline Subtriquetra sp. 1 (ZUFMS-INV No. 005) & swimming bladder & 7.69 & $0.13 \pm 0.6$ & $1.71 \pm 1.49$ & $1-5$ \\
\hline Subtriquetra sp. 2 (ZUFMS-INV No. 006) & swimming bladder & 10.98 & $0.23 \pm 0.83$ & $2.1 \pm 1.59$ & $1-6$ \\
\hline
\end{tabular}

$\mathrm{SI}=$ site of infection; $\mathrm{P}(\%)$ = prevalence; $\mathrm{MA}$ = mean abundance; $\mathrm{MI}=$ mean intensity; $\mathrm{RV}$ = range of variation; $\mathrm{SD}=$ standard deviation. 


\section{Acknowledgements}

The authors thank Marcelo Knoff $\mathrm{PhD}$. This study was partially supported by Fundação de Apoio ao Desenvolvimento do Ensino, Ciência e Tecnologia do Estado de Mato Grosso do Sul (FUNDECT). W. Vicentin and K.R.I. Vieira were supported by a student fellowship from FUNDECT and Conselho Nacional de Desenvolvimento Científico e Tecnológico (CNPq), respectively.

\section{References}

AZEVEDO, R. K.; ABDALLAH, V. D.; LUQUE, J. L. Ecologia da comunidade de metazoários parasitos do acará Geophagus brasiliensis (Quoy e Gaimard, 1824) (Perciformes: Cichlidae) do rio Guandu, Estado do Rio de Janeiro, Brasil. Acta Scientiarum Biological Sciences, v. 28, n. 4, p. 403-411, 2006.

BOEGER, W.A.; TANAKA, L. K.; PAVANELLI, G. C. Neotropical Monogenoidea. 39: A new species of Kritskyia (Dactylogyridae, Ancyrocephalinae) from the ureters and urinary bladder of Serrasalmus marginatus and S. spilopleura (Characiformes, Serrasalmidae) from southern Brazil with an emended generic diagnosis. Zoosystema, v. 23, n. 1 , p. 5-10, 2001.

BUSH, A. O. et al. Parasitology meets ecology on its own terms: Margolis et al. revisited. Journal of Parasitology, v. 83, n. 4, p. 575-583, 1997.

EIRAS, J. C.; TAKEMOTO, R. M.; PAVANELLI, G. C. Métodos de estudo e técnicas laboratoriais em parasitologia de peixes. 2. ed. Maringá: EDUEM, 2006. 171 p.

GIESE, E. G.; SANTOS, J. N.; LANFREDI, R. M. A new species of Camallanidae from Ageneiosus ucayalensis (Pisces: Siluriformes) from Pará State, Brazil. Journal of Parasitology, v. 95, n. 2, p. 407-412, 2009.

GUIDELLI, G. M. Comunidades parasitárias em espécies de peixes congenéricas de diferentes categorias tróficas e ambientes da planície de inundaçáo do Alto rio Paraná. 2006. 91 f. Dissertaçáo (Mestrado)Universidade Estadual de Maringá, Maringá.
LACERDA, A. C. F. Endoparasitos de raias fluviais Potamotrygon falkneri e Potamotrygon motoro (Chondrichthyes: Potamotrygonidae) da planície de inundaçáo do alto rio Paraná: taxionomia e aspectos ecológicos. 2007. 45 f. Dissertação (Mestrado)-Universidade Estadual de Maringá, Maringá.

MORAVEC, F.; PROUZA, A.; ROYERO, R. Some nematode of freshwater fishes in Venezuela. Folia Parasitologica, v. 44, n. 1, p. 33-47, 1997.

NIEWIADOMSKA, K. Superfamily Diplostomoidea Poirier, 1886. In: GIBSON, D. I.; JONES, A.; BRAY, R. A. (Ed.). Keys to the trematoda. vol. I. London: The Natural History Museum, 2002. p. 159-166.

PAVANELLI, G. C. et al. Helminth fauna of fishes: diversity and ecological aspects. In: THOMAZ, S. M.; AGOSTINHO, A. A.; HAHN, N. S. (Ed.). The upper Paraná river and its floodplain: physical aspects, ecology and conservation. Netherlands: Backhuys Publishers, Leiden, 2004. v. 1, p. 309-329.

REGO, A. A. Contribuiçáo ao conhecimento dos helmintos de raias fluviais Paratrygonidae. Revista Brasileira de Biologia, v. 39, n. 4, p. 879-890, 1979.

REGO, A. A.; EIRAS, J. Identificação das larvas de Sebekia e Leiperia (Pentastomida) histopatologia em peixes de rios. Revista Brasileira de Biologia, v. 49, n. 2, p. 591-595, 1989.

SPRENT, J. F. A. Some ascaridoid nematodes of fishes: Heterocheilinae. Systematic Parasitology, v. 16, n. 3, p. 149-161, 1990.

TANAKA, L. K. Aspectos ecológicos dos parasitos de Serrasalmus marginatus Valenciennes, 1847 e Serrasalmus spilopleura Kner, 1860 (Characiformes, Serrasalmidae) do rio Baía, Planície de inundaçáo do alto rio Paraná, MS. 2000. 32 f. Dissertação (Mestrado)-Universidade Estadual de Maringá, Maringá.

TRAVASSOS, L.; FREITAS, J. F. T. Pesquisas Helmintológicas - II. Memórias do Instituto Oswaldo Cruz, v. 35, n. 3, p. 610-633, 1940. 